\title{
Multi-seam mining of the deep Waterberg resources
}

\author{
by C.K. Chabedi* and T. Zvarivadza*
}

\section{Synopsis}

This paper discusses the difficulties associated with the potential exploitation of the deep multi-seam resources east of the Daarby fault in the Waterberg coalfield. The resources occur at a depth greater than $250 \mathrm{~m}$ and the thickness of the coal is roughly $110 \mathrm{~m}$, but the top $50 \mathrm{~m}$ comprises coal intercalated with shale and the bottom $60 \mathrm{~m}$ contains five seams with sandstone and shale partings. Various factors affecting multiple seam mining at these great depths are discussed with reference to lessons learned from local and international experience on multi-seam mining. Field geological and geotechnical data was utilized to assess the stability of the roof of the seams. There is no specific rock mass rating for the Waterberg area, therefore approximate coal mine roof rating (CMRR) values were used to propose appropriate support strategies. Analysis of Multiple Seam Stability (AMSS) was used to analyse the strength of the parting or interburden between the various seams, the mining sequence, and the interaction between the various seams.

The research indicated that it is possible to mine seams with a low CMRR at high mining rates using longwall mining, although support for gateroads is expected to be expensive, time-consuming and onerous to install, and will impact gateroad development rates. It will not be possible to simultaneously mine zones in close proximity and failure of the interburden is predicted, thus dangerous mining conditions are anticipated. However, it will be possible to mine just two of the eleven zones using longwall mining.

Keywords

multi-seam mining, Waterberg, coal mining, longwall, coal mine roof rating (CMRR), Analysis of Multiple Seam Stability (AMSS).

\section{Introduction}

This paper discusses the difficulties associated with the potential exploitation of the deep multi-seam resources east of the Daarby fault in the Waterberg coalfield using bord and pillar and longwall mining. Figure 1 illustrates the location of the Waterberg coalfield relative to other coalfields in South Africa, while Figure 2 shows the areas containing deep and shallow resources. The Waterberg resources are expected to contribute to South Africa's future energy requirements, and are currently exploited at the Grootegeluk open pit mine. Grootegeluk produces coal mainly for a power station, with the higher quality product supplied as metallurgical coal. The deposit is technically unique and challenging, being a multi-seam coal deposit with a total of 12 seams over a thickness of $110 \mathrm{~m}$ as shown in
Figure 3, including Zone 5. There is currently limited knowledge on the multi-seam mining of the deep Waterberg resources. Multi-seam mining utilizing the bord and pillar method has been practised in South Africa before, but at a depth of less than $100 \mathrm{~m}$ in the Witbank coalfields. Multi-seam mining in thin seams has also been performed in the Natal coalfields at a depth of less than $160 \mathrm{~m}$, but mostly using bord and pillar mining and secondary mining (partial pillar extraction).

However, past experience with multi-seam mining at depths greater than $250 \mathrm{~m}$ in South Africa is limited. It is therefore critical to review multi-seam mining experience in other countries where the depth of mining is greater than $250 \mathrm{~m}$.

\section{Previous multi-seam mining in South Africa and associated limitations}

South Africa has over 19 recognized coalfields as indicated in Figure 1, only 10 of which are producing coal. The Central Basin, constituting the Witbank, Highveld, and Ermelo coalfields, is responsible for over $80 \%$ of the run-of-mine (RoM) production (Chabedi and Phillips, 2012). The Witbank and Highveld coalfields together account for over $75 \%$ of the RoM and the Witbank coalfield alone accounts for over $55 \%$ of the RoM produced over the past 20 years (Prevost, 2011). In the past 30 years two major seams (No. 2 and No. 4 seams) have been exploited in the Witbank and Highveld coalfields because of good mining conditions, i.e. horizontal, shallow seams from 2-6 m thick at depths of less than $150 \mathrm{~m}$. Although the No. 2 seam occurs at a greater depth than the No. 4 seam, it was exploited first because of its higher export value. The mining

* School of Mining Engineering, University of the Witwatersrand, Johannesburg, South Africa.

(C) The Southern African Institute of Mining and Metallurgy, 2016. ISSN 2225-6253. Paper received Apr. 2016; revised paper received Oct. 2016. 


\section{Multi-seam mining of the deep Waterberg resources}

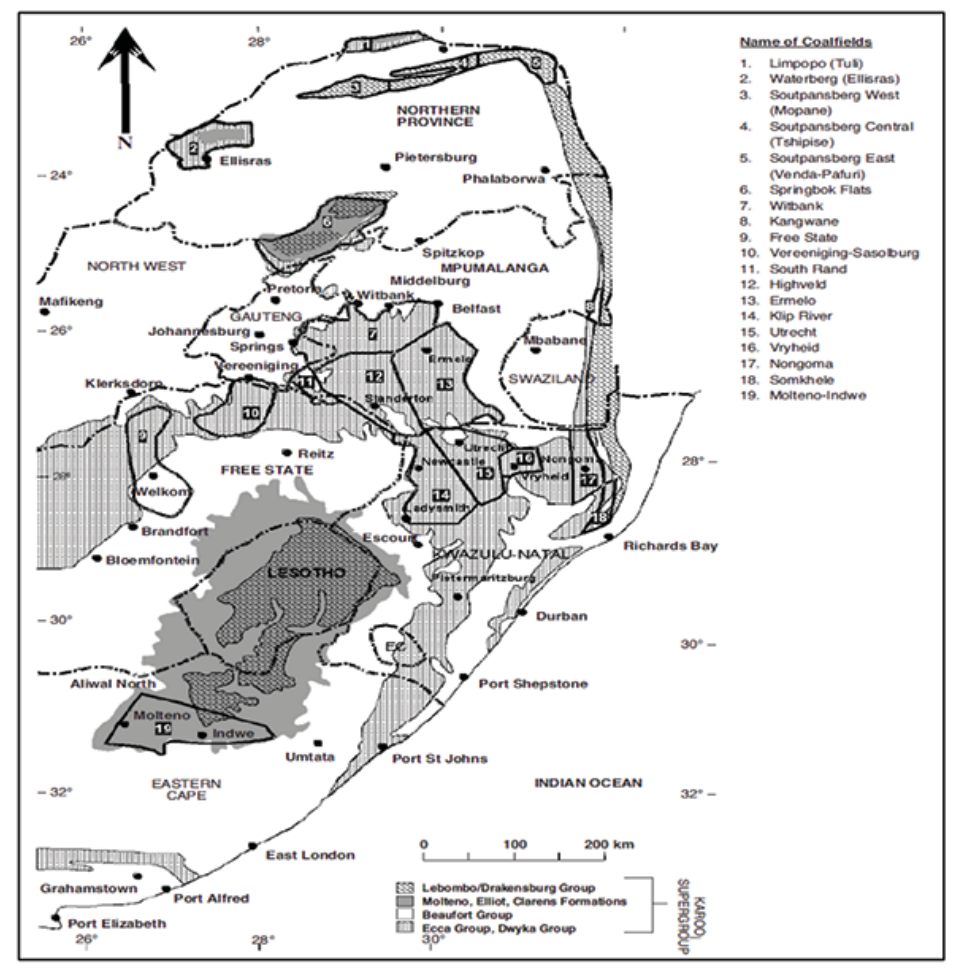

Figure 1-Location of the Waterberg coalfield, shown as coalfield number 2 (Jeffrey, 2005)

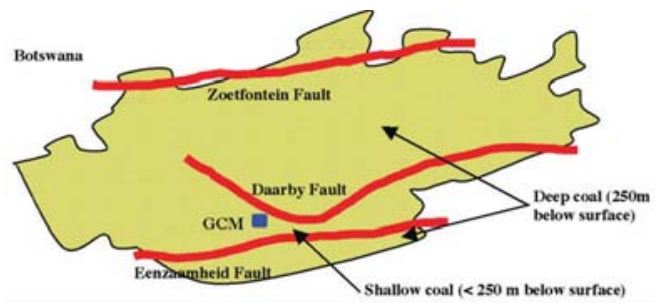

Figure 2-Deep and shallow coal areas in relation to Grootegeluk coa mine (GCM) (Jeffrey, 2005)

sequence was therefore value-driven rather than designdriven. The No. 2 seam is extensively mined by bord and pillar methods, whereas the No. 4 seam is mined to a lesser extent. Pillars are either superimposed or not, taking into account various issues such as the thickness and competence of the parting between the No. 2 and No.4 seam, depth below surface, seam thicknesses, and mining heights of the two seams. Pillar extraction has generally not been extensively carried out in either the No. 2 or No. 4 seam because of the safety risks (Hill, 1995). Recently the No. 5 seam has been mined before the No. 2 and No. 4 seams in the Witbank and Highveld coalfields, except in certain areas where this is prevented by the thickness and high stripping ratios. Where the No. 5 seam is mined it is thin i.e. less than $2 \mathrm{~m}$ and tends to be mined by underground mining methods.

Multi-seam mining has also been carried out in the Natal coalfields, but the seams are generally thin (less than 1-2 m thick) and occur at an average depth of less than $160 \mathrm{~m}$. The thickness of the partings between the seams made it possible for as many as four to five seams to be exploited in the past,

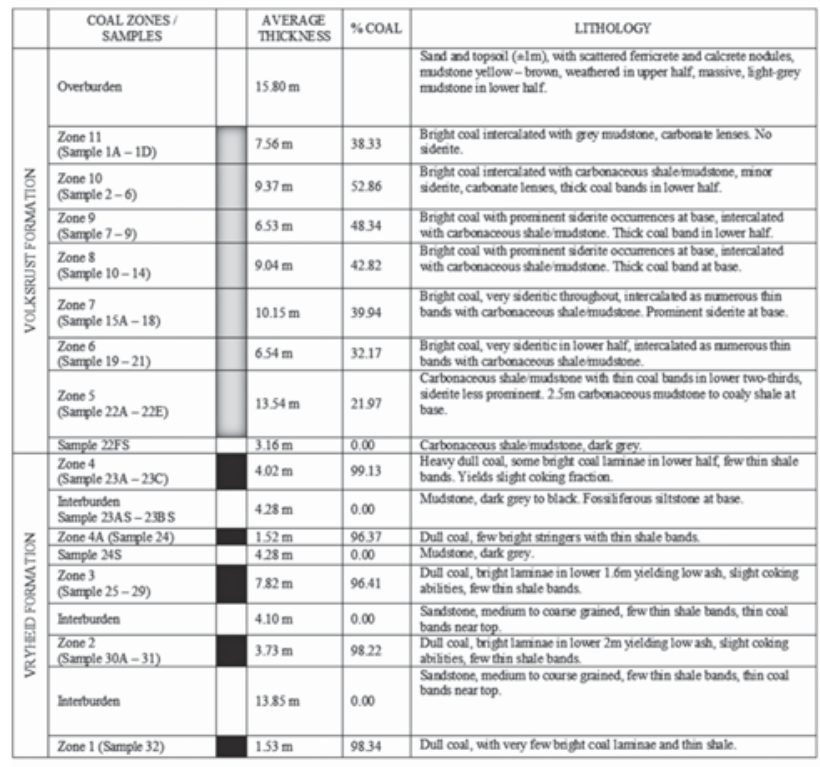

Figure 3-The stratigraphic column of the Grootegeluk and Vryheid formations of the Waterberg in the Grootegeluk coal mine area (Dreyer, 1994)

despite the thin seams. The quality of the coal, which is anthracite and coking coal, makes it suitable for the export market, therefore total extraction with bord and pillar mining and subsequent overmining and undermining was employed (Hill, 1995). The term overmining means that the lower seam is mined prior to the upper seam (active) seam; the reverse applies for undermining (Mark, 2007). 


\section{Multi-seam mining of the deep Waterberg resources}

Multi-seam mining with more than one mining method at depths greater than $250 \mathrm{~m}$ has not been done in South Africa before. It is therefore important to determine whether it is possible to mine multiple seams in the Waterberg coalfield at greater depth with more than one mining method. The Waterberg coal resource has a total thickness of $110 \mathrm{~m}$, consisting of 5 seams at the bottom of the stratigraphy (referred to as the Middle Ecca) separated by sandstone partings and the top $60 \mathrm{~m}$ (the Upper Ecca) made up of coal intercalated with shale as shown in Figure 3. Exploitation of a package of seams $110 \mathrm{~m}$ thick at a depth greater than 250 $\mathrm{m}$ would require mining to be done in phases.

\section{Factors affecting multi-seam mining}

Van der Merwe and Madden (2010) stated that multi-seam mining is generally affected by a number of factors such as:

1. Parting thickness. The greater the parting thickness between two seams being mined, the less the interaction between the seams

2. Parting characteristics. Sandstones and shales are dominant rock types in most of South African coalfields and each rock type will influence a multiseam situation differently. Sandstone layers tend to be relatively massive and are known to span much wider panels than thinly laminated shales. Therefore, the stiffness of the sandstone layers in the parting tends to dampen the effect of stress transfer from one seam to another. The effect of having a sandstone roof compared to a shale roof was studied before a decision could be made on what coal seams to mine with multiseam mining at the Waterberg coalfield

3. Mining method. Low-extraction methods such as bord and pillar have less influence on other seams than high-extraction layouts such as longwall

4. Relative location of layouts. In high-extraction layouts such as longwall the gateroads of the lower seams must be located below the goaf of the upper seam in order to protect them from high stresses from the upper seam, especially when the parting is thin and not competent. In low-extraction methods such as bord and pillar, roadway and pillar stability depends on the close proximity of the seams mined as well as whether the pillars are superimposed or not

5. Percentage recovery. It is expected that in highextraction mining methods the percentage recovery of the upper seams would create better conditions in the lower seams. Stress transfer to lower seams is likely where remnant pillars are present, and hence this situation should be avoided.

In addition to the above, Mark et al. (2007) listed the following factors that affect multiple seam interaction.

1. Depth of cover. As the depth of mining increases, multiple seam mining induces a greater potential stress concentration

2. Mining sequence. Generally, undermining is better that overmining when geotechnical considerations outweigh economic benefits. Overmining tends to cause subsidence and damage to the upper seams
3. Stability of the immediate roof of the seam mined. This is dependent on aspects such as the strength, discontinuities, water content, and moisture sensitivity of the roof above the seam mined, which (among other factors) give rise to a coal mass rock rating (CMRR) value (Mark and Molinda, 2005). CMRR values of greater than 65 are considered high, and those less than 40 as weak

4. Stability of the immediate floor of the seam mined. Unstable or weak floor tends to break or be slippery, making it difficult to manoeuvre or operate machinery. It is preferable for the floor to be competent.

Given the complexity and variability of all the factors mentioned above, calibrated numerical modelling tools are the best option for modelling dynamic stresses and interactions caused by mining multiple seams.

\section{Considerations for underground mining of the Waterberg resources/reserves}

As mentioned previously, current coal mining in the Waterberg coalfield is by open pit mining at Grootegeluk, which supplies a power station and produces some metallurgical coal. Underground multi-seam mining of the Waterberg resources is expected to involve different design and operational factors from current mining at the Witbank and Highveld coalfields. Underground mining with a highextraction mining method such as longwall would be preferable in order to deliver coal at the highest tonnages at a low cost for power generation. Therefore the first consideration is longwall as the method of choice, and thereafter the number of seams to be mined in both the Upper and the Middle Ecca, taking into consideration the multi-seam factors outlined earlier.

The first general manager of Grootegeluk proposed that two zones in the Upper Ecca could be mined by underground methods because of the size of the underground resource, despite the numerous geotechnical problems likely to be encountered. The zones or seams proposed to be mined were Zones 10 and 9, and 9 and 8, with a seam thickness of about $2.4 \mathrm{~m}$ each and ash contents of $36.3 \%$ and $25.9 \%$ respectively (Alberts, 1987). After taking into account the uniaxial compressive strength (UCS) of the roof, which is in this case is shale and coal, the moisture sensitivity, the point load estimates, groundwater, and using different data from the core information given in Table I, the resultant CMRR of Zones 9 and 8 with a suitable power station calorific value (CV) was calculated to be about 37 . The calculation takes into account the UCS, point load estimates and the subtotal of the fractures, the rock quality designation (RQD), and the diametral information. Zones 10 and 9 were not suitable due to their high ash content compared to Zones 9 and 8 .

The low CMRR of Zone 9 means that additional support would be required in the longwall gates as the mining conditions are expected to be very difficult. Further research using the NIOSH database of US coal mines confirmed that longwall mining is possible with a low CMRR of about 30 (Mark and Molinda, 2005). A number of the mines with low CMRR were mining high tonnages using longwall mining methods but using additional roof support and narrower bord 


\section{Multi-seam mining of the deep Waterberg resources}

\begin{tabular}{|l|l|}
\hline \multicolumn{2}{|l|}{$\begin{array}{l}\text { Table I } \\
\text { for Zone } 9\end{array}$} \\
\hline Input & Value \\
\hline 1. Bolt length & $1.8(\mathrm{~m})$ \\
\hline 2. Groundwater adjustment & Damp \\
\hline 3. Surcharge adjustment & $\begin{array}{c}\text { Roof above bolts is much weaker } \\
\text { than the bolted interval }\end{array}$ \\
\hline 4. Unit description & Shale/coal \\
\hline 5. Thickness & $2.4 \mathrm{~m}$ \\
\hline 6. Depth to unit & $298 \mathrm{~m}$ \\
\hline 7. Average axial IS & $1.6 \mathrm{MPa}$ \\
\hline 8. Average axial UCS & $34 \mathrm{MPa}$ \\
\hline 9. Diametral PLT & No data available \\
\hline 10. Fractures & No fractures observed \\
\hline 11. PLT estimate & Weak \\
\hline 12. Moisture & Moderately sensitive \\
\hline
\end{tabular}

Note: IS - point load strength index; UCS (uniaxial compressive strength; PLT - point load testing)

widths when the chain roads are developed. South African coal is known to be harder than US coal and the RMRs indicate that CMRR values higher than 30 are expected at the Waterberg coalfield, as indicated above. The implication of this is that it would be possible to apply the CMRR method to evaluate the Waterberg coalfield roof types and propose a longwall operation at low CMRR. In general, support requirements for low-CMRR gateroads are expected to be onerous, time-consuming to install, expensive, and will impact gateroad development rates.

The stratigraphy and mining parameters for the coal zones of the Middle Ecca are summarized in Table II. Zones 1 and $4 \mathrm{~A}$ are considered too thin for mining, being less than $1.5 \mathrm{~m}$. Where the roof type is friable, such as when there is shale instead of sandstone and the parting thickness is less than 6-9 $\mathrm{m}$ it is not possible to mine using longwall on the two seams in close proximity without incurring poor ground conditions (Haycocks and Zhou, 1990). The parting thickness between the zones is less than $4 \mathrm{~m}$ except between
Zones 1 and 2, and both the roof and floor are competent only in Zones 1 and 2. If the thickness of the seams or zones is taken into account, only Zone 2 , with a thickness of $4 \mathrm{~m}$, will be mined without experiencing geotechnical challenges.

Zone 2 is the preferred mining horizon in the Middle Ecca taking into account the mining thickness and all geotechnical considerations, including the evaluation of the roof using the CMRR and the competency of the floor. Using preliminary data indicated in Table III, the CMRR of Zone 2 was calculated to be 54 ; the actual CMRR might be higher or lower.

Lastly, because the resource of Zone 3, which is $8 \mathrm{~m}$ thick, is potentially large and the parting between Zones 3 and 2 is $4 \mathrm{~m}$ and competent, it is important to evaluate, using numerical methods, whether it is possible to mine both Zone 3 and Zone 2 by longwall and room and pillar in a descending order. This will ensure that all possible planning configurations have been tested and that no coal is left in this zone that could have been mined. It is with this end in mind that this mining option was evaluated.

Table III

Drill core input information for calculating CMRR for Zone 2

\begin{tabular}{|l|c}
\hline Input & Value \\
\hline Bolt length & $1.8(\mathrm{~m})$ \\
\hline Ground water adjustment & Dry \\
\hline Surcharge adjustment & $\begin{array}{c}\text { Roof above bolts is stronger } \\
\text { than the bolted interval }\end{array}$ \\
\hline Unit description & Sandstone \\
\hline Thickness & $4 \mathrm{~m}$ \\
\hline Depth to unit & $350 \mathrm{~m}$ \\
\hline Average axial IS & $1.6 \mathrm{MPa}$ \\
\hline Average axial UCS & $71 \mathrm{MPa}$ \\
\hline Diametral PLT & No data available \\
\hline Fractures & No fractures observed \\
\hline PLT estimate & Moderate \\
\hline Moisture & Not sensitive \\
\hline
\end{tabular}

\section{Table II}

Coal zones in the Middle Ecca (Chabedi and Phillips, 2012)

\begin{tabular}{|c|c|c|c|c|c|}
\hline Zone & Coal thickness (m) & Roof & Floor & Parting (m) & $\%$ Ash \\
\hline 4 & 4.1 & Shale & Shale & & 43 \\
\hline Parting & & & & 4.3 & \\
\hline $4 \mathrm{~A}$ & $<1.5$ & Shale & Shale & & \\
\hline Parting & & & & 4.2 & \\
\hline 3 & 8 & Shale & Sandstone & & 30 \\
\hline Parting & & & & 4.0 & \\
\hline 2 & 4 & Sandstone & Sandstone & & 25 \\
\hline Parting & & & & 14 & \\
\hline 1 & $<1.5$ & & & & 21 \\
\hline
\end{tabular}




\section{Multi-seam mining of the deep Waterberg resources}

\section{Analysis of Multiple Seam Stability (AMSS) and mining consideration}

To evaluate the potential multiple seam interactions the Analysis of Multiple Seam Stability (AMSS) software was used (Mark et al., 2007). AMSS is an empirical design technique that was derived from statistical analysis of a database of 344 multiple seam case histories from 36 USA coal mines (Mark et al., 2007). Although the Waterberg is outside the AMSS database, the geology and mining methods are similar enough for AMSS to be considered appropriate for an initial feasibility analysis.

The AMSS software allows the user to input a variety of geometric and mining parameters which assist mine planners to understand the potential interaction of the various seams and to take steps to reduce the risk of ground control failure. The program automatically runs the necessary LaM2D (La Model) and Analysis of Longwall Pillar Stability (ALPS). The primary output from AMSS is a three-level (green/yellow/red) prediction of the intensity of the multiple seam interaction that is likely to be encountered (Mark et al., 2007).

Three scenarios were investigated in order to determine which seams were mineable by underground mining; the three seams are Zone 9, Zone 3, and Zone 2. Zone 2, with its competent sandstone roof, would be the first seam mined by longwall mining and therefore it is not necessary to do an ASMM on this seam. The mining of Zone 3 and Zone 9, which are the subsequent zones to be mined, was analysed using the ASMM model.

The input parameters for Zone 9 stability analysis using AMSS are shown in Figures $4 \mathrm{a}$ and $4 \mathrm{~b}$ respectively.

The results of the AMSS analysis for Zone 9, with a CMRR of about 37 , indicate 'green', meaning a major interaction of the seams is unlikely. However, additional support would be required in the longwall gates as the conditions are expected to be very difficult. The mining of Zone 2, with a CMRR of 54, by longwall mining has already been established in the previous paragraphs and therefore there is no need to do an AMSS analysis.

The mining of Zone 3 by longwall and Zone 2 by bord and pillar requires that the CMRR rating of both roofs, the strength of the interburden between the zones, the sequencing, and stress interaction of both seams are analysed. The objective is to determine what room and pillar and longwall layouts would be possible

The input parameters for testing the technical viability of the mining of the longwall in Zone 3 were a CMRR of 54 , interburden of $4 \mathrm{~m}$, a seam height of $4 \mathrm{~m}$ for the longwall to be exploited, and face width of the longwall block of $200 \mathrm{~m}$, which is typical of longwalls in South Africa. The input parameters for room and pillar in Zone 2 were a seam height of $4 \mathrm{~m}$, the depth of mining to the roof $354 \mathrm{~m}$, bord width $6 \mathrm{~m}$, centre distance of $40 \mathrm{~m}$ after calculating a pillar size of $34 \mathrm{~m}$, and mining a typical 7-roadway section. The inputs for this scenario are shown in Figure 5.

\section{Results of the AMSS analysis}

The AMSS results showed a 'red' level of risk for the mining of Zone 3. This means that a major interaction should be considered likely in the chain roads, even if a pattern of supplemental roof support is installed on the chain roads of the longwall and all the roadways in the bord and pillar working in Zone 2. The model indicates that it is not possible to mine both zones, as was expected. It was concluded that the area is to be avoided. Mining of Zones 3 and 2 by longwall and bord and pillar is impossible without a major multiple seam interaction, primarily as a result of the thin interburden of $4 \mathrm{~m}$. The predicted conditions would not allow any mining even when intensive roofbolting is installed, as discussed. Other configurations were tested, such as mining both zones by longwall and mining Zone 3 by bord and pillar and Zone 2 by longwall, but the numerical models still indicate that it would not be possible to mine both seams without a major interaction.

The AMSS analysis indicate that it was possible to do multi-seam mining of Zones 9 and 2 in order to mine Zone 9 however, it is not possible to do multi-seam mining of Zones 3 and 2 where the depth of mining is above $250 \mathrm{~m}$. The current geotechnical data and multi-seam considerations using numerical models indicate that only two zones, Zones 2 and 9 , could be mined by underground mining methods such as longwall at the high rate and low cost required to supply a power station.
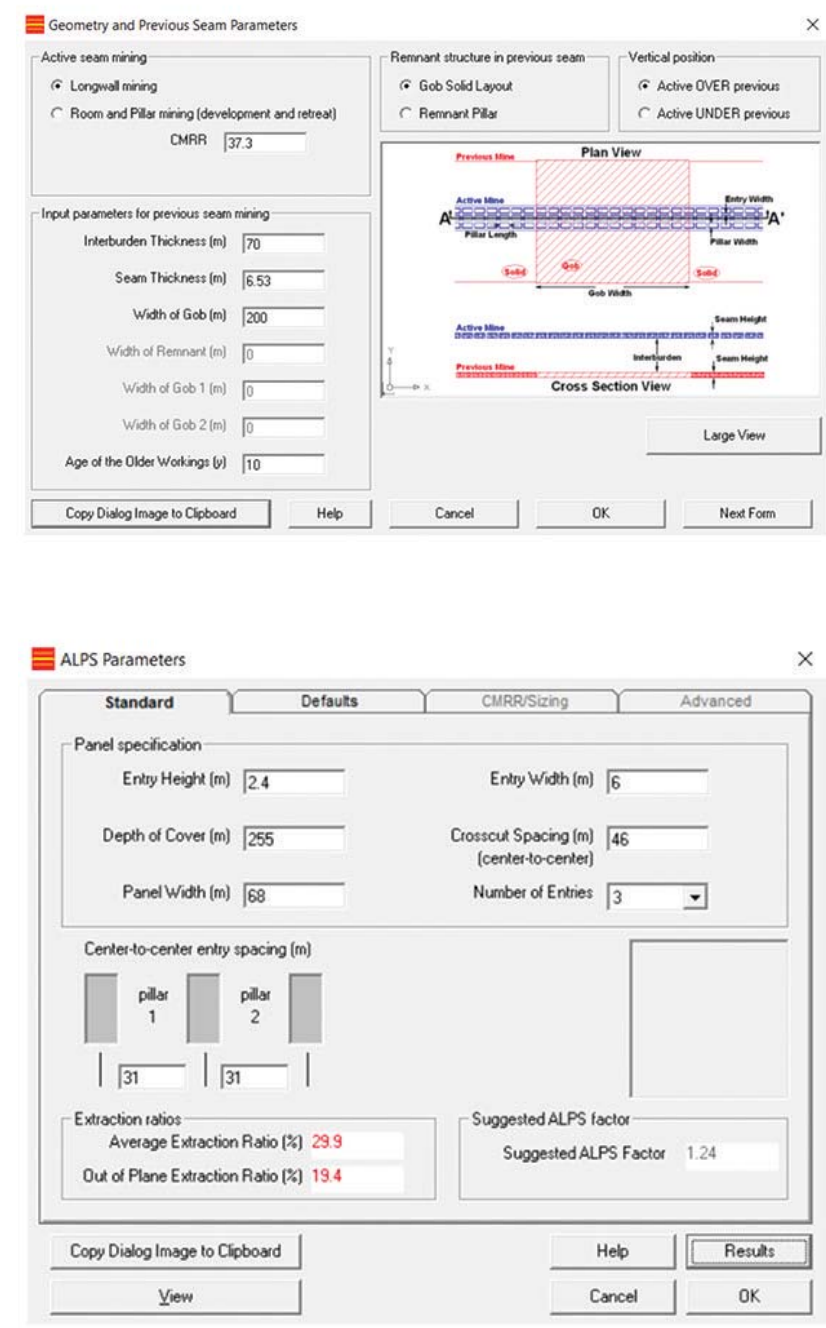

Figure 4-AMSS input data for Zone 9 


\section{Multi-seam mining of the deep Waterberg resources}
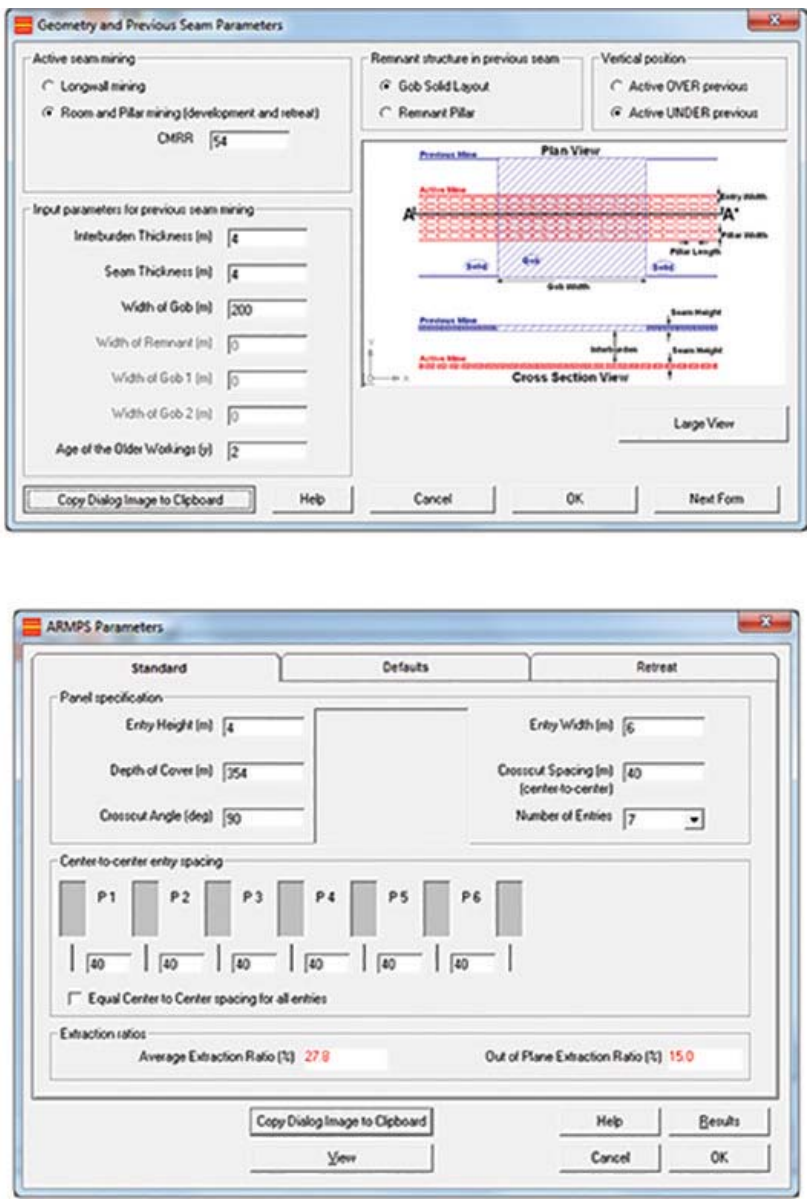

Figure 5-AMSS bord and pillar input for Zone 3

\section{Concluding remarks}

The purpose of this paper was to determine if exploitation of the deep resources in the Waterberg coalfield would be feasible by underground mining methods. Two zones for mining were identified for possible high-output, low-cost longwall mining, i.e. Zones 9 and 2.

Analysis of the CMRR indicated that it is possible to mine Zone 2 by longwall mining by using an estimated CMRR value of 54 as an initial step. However, it is important to note that the actual CMRR value of Zone 2 might be higher or lower by 10 points, implying that the CMRR could be as high as 64 or as low as 44 . Within the CMRR range of 44 to 64 mining of Zone 2 is still feasible. Other seams in the Middle Ecca are not mineable, i.e. Zone 1, 3, 4, 4A when the interburden thickness is taken into account and the roof and floor competency are considered.

The evaluation also indicated that it is possible to mine Zone 9 , which has a seam thickness of about $2.4 \mathrm{~m}$, by longwall mining methods despite the intercalated nature of the roof and floor, which have a CMRR of less than 40 . However, additional support would be required in the longwall gates as the conditions are expected to be very difficult. Further research using the NIOSH database of US coal mines confirmed that longwall mining is possible for CMRRs of around 30.
In the final analysis two seams, Zone 2 in the Middle Ecca and Zone 9 in the Upper Ecca, can be mined from the Waterberg deep underground resources with extra support required when the gateroads are developed as difficult mining conditions are expected.

\section{References}

AlBERTS, B. 1987. Presidential Address: Planning the utilization of South Africa's coal reserves. Journal of the South African Institute of Mining and Metallurgy, vol. 87, no. 11. pp. 371-395.

Chabedi, K.C. and Phillips, H.R. 2012. The future contribution of coal to the energy requirements of South Africa. Proceedings of the Society of Mining Professors Conference, KGHM Cuprum Spolka Zoo Centrum Badawo Rozwojowe, Wraclaw, Poland. pp. 15-26

DREYER, C. 1994. Total utilization of the coal resource: the Grootegeluk experience. Proceedings of the XVth CMMI Congress. Anhaeusser, C. (ed.). South African Institute of Mining and Metallurgy, Johannesburg. pp. 153-164.

JeFFREY, L. 2005. Characterization of the coal resources of South Africa. Journal of the South African Institute of Mining and Metallurgy, vol. 105, no. 2. p. 96.

Haycocкs, C. and Zноu, Y. 1990. Multiple-seam mining - a state-of-the-art review. Proceedings of the 9th Conference on Ground Control in Mining, Morgantown, WV. pp. 1-11.

HILL, R. 1995. Multi-seam mining on South African Collieries. Proceedings of the 14th Conference on Ground Control in Mining, Morgantown, WV. Peng, S.S. (ed.). pp. 305-311.

MARK, C. 2007. Multiple-Seam Mining in the United States: Background. National Institute for Occupational Safety and Health (NIOSH), Pittsburgh.

MARK, C., ChASE, F.E., and PAPPAS, D.M. 2007. Analysis of multiple seam stability. Proceedings of the 26th Conference on Ground Control in Mining, Morgantown, WV. National Institute for Occupational Safety and Health, Washington, DC. pp. 5-18.

MARK, C. and MolindA, G. 2005. The Coal Mine Roof Rating (CMRR) - a decade of experience. International Journal of Coal Geology, vol. 64, no. 1-2. pp. $85-103$.

Prevost, X. and FALCon, R. 2011. Coal resources and reserves overview. Johannesburg. [Unpublished].

VAN DER MERWE, J.N. and MADDEN, B.J. 2010. Rock Engineering of Underground Coal Mining. 2nd edn. Southern African Institute of Mining and Metallurgy, Johannesburg. 